\title{
PEKERJA ANAK SEBAGAI KEARIFAN LOKAL
}

\author{
Ahmad Yasser Effendi ${ }^{1}$
}

\begin{abstract}
Abstrak
Desa Bogak merupakan wilayah pesisir yang sebagian besar masyarakatnya mencari nafkah dari laut. "Anak itik" adalah istilah kearifan lokal untuk anak-anak yang membantu nelayan di Desa Bogak dan sudah disosialisasikan secara turun temurun. Kearifan lokal ini sudah diturunkan dari generasi ke generasi dengan konformitas yang ada di masyarakat bahwa "anak itik" tersebut nantinya akan menjadi pelaut atau nelayan di Desa Bogak.Sebagian besar hak "anak itik" sebagai anak-anak tidak terpenuhi, namun hal itu tidak disadari oleh masyarakat Desa Bogak (termasuk “anak itik"). Hal itu disebut juga sebagai kekerasan simbolik, yaitu kekerasan yang tidak disadari karena berbagai simbol yang menutupinya. Tulisan ini akan mengidentifikasi kekerasan simbolik yang dirasakan oleh "anak itik". "Anak itik" tidak menyadari kekerasan atau ketidakterpenuhinya hak-hak mereka sebagai anak, baik yang harus dipenuhi oleh keluarga atau juga masyarakat. "Anak itik" merupakan kearifan lokal yang ada di Desa Bogak dan merupakan proses bagi anak-anak di sana untuk menjadi pribadi yang dewasa, memahami laut, sehingga menjadi budaya yang harus diturunkan dari generasi ke generasi.
\end{abstract}

Kata Kunci: Pekerja Anak, Hak Anak, Masyarakat Pesisir, Kearifan Lokal dan Kekerasan Simbolik

\footnotetext{
${ }^{1}$ Mahasiswa Pascasarjana, S2 Sosiologi Fakultas Ilmu Sosial dan Ilmu Politik Universitas Gadjah Mada
} 


\section{PENDAHULUAN}

Indonesia merupakan negara maritim dengan luas laut seluas $64,85 \%$ dari luas wilayah Indonesia atau 3.544.743,9 $\mathrm{km}^{2}$ (Kementerian Kelauatan dan Perikanan, 2011). Dengan demikian, Indonesia dapat dikatakan sebagai produsen hasil kelautan terbesar nomor 5 di dunia (Adam, 2015). Sehingga dalam menunjang produksi yang sedemikian rupa, industri kelautan membutuhkan tenaga kerja yang tinggi. Desa Bogak, Kecamatan Tanjung Tiram, Kabupaten Batubara, Sumatera Utara memiliki jumlah penduduk sebanyak 4.974 orang. Jumlah penduduk tersebut jika diklasifikasikan berdasarkan jenis kelamin adalah 2.478 lakilaki dan 2.495 perempuan dengan jumlah kepala keluarga sebanyak 1251 KK. Berdasarkan data yang ditemukan di kantor kepala desa bahwa terdapat 579 KK penduduk miskin dan yang mendapat kartu sehat sebanyak 550 jiwa (Profil Desa, 2013).

Mayoritas pekerjaan penduduknya adalah nelayan dengan presentase $90 \%$ dari total penduduk. Masyarakat tersebut mayoritas memiliki tingkat kesejahteraan yang rendah dikarenakan perekonomian mereka sebagian besar bergerak disektor nelayan yang pendapatannya dipengaruhi dari hasil penangkapan ikan serta sangat dipengaruhi oleh keadaan alam. Hal ini dibuktikan oleh data kependudukan desa tahun 2013 bahwa pendapatan perkapita masyarakat setempat hanya mencapai rata-rata $35 \mathrm{ribu} / \mathrm{hari}$. Tentu saja pendapatan tersebut masih tergolong rendah jika harus memenuhi biaya kehidupan sehari-hari seperti makan, pendidikan, serta biaya hidup lainnya. Sehingga pendidikan anak-anak yang ada di desa tersebut sangat rendah, bahkan sebagian dari mereka harus putus sekolah karena lebih mementingkan membantu orang tua daripada melanjutkan pendidikan.

Anak adalah seseorang yang belum berusia 18 (delapan belas) tahun, termasuk anak yang masih dalam kandungan (UU No. 23 tahun 2002 tentang perlindungan anak). Anak merupakan tunas bangsa yang merupakan generasi penerus di masa depan. Dalam diri seorang anak terdapat hak-hak manusia seutuhnya. Berbeda dengan kategori dewasa, anak-anak memiliki hak-hak lebih daripada kewajibannya.

Ada berbagai faktor yang menyebabkan seorang anak menjadi pekerja atau buruh. Menurut Endrawati (2011) ada beberapa faktor yang mempengaruhi anakanak menjadi pekerja di sektor informal adalah sebagai berikut: 
Tabel Data Pekerja Anak Berdasarkan Faktor Penyebab

\begin{tabular}{|l|l|l|l|}
\hline NO & $\begin{array}{l}\text { Faktor } \\
\text { Penyebab } \\
\text { Bekerja }\end{array}$ & $\begin{array}{l}\text { Jumlah } \\
\text { Pekerja Anak }\end{array}$ & Prosentasi \\
\hline 1 & $\begin{array}{l}\text { Diajak } \\
\text { Teman }\end{array}$ & 22 & $44 \%$ \\
\hline 2 & Orang tua & 8 & $16 \%$ \\
\hline 3 & $\begin{array}{l}\text { Diajak } \\
\text { tetangga }\end{array}$ & 7 & $14 \%$ \\
\hline 4 & $\begin{array}{l}\text { Ikut- } \\
\text { ikutan / } \\
\text { coba-coba }\end{array}$ & 13 & $26 \%$ \\
\hline N & & 50 & $100 \%$ \\
\hline
\end{tabular}

(Sumber: Endrawati, 2011)

Data di atas menunjukkan bahwa sebagian besar anak-anak yang bekerja di sektor informal dikarenakan ajakan dari teman bermain. Hal tersebut menunjukkan bahwa pekerja anak-anak tersebut banyak menghabiskan waktu bersama dengan teman sebaya mereka. Dalam hal ini, mereka banyak mengganti waktu bermain mereka menjadi waktu bekerja.

Masyarakat perdesaan maupun masyarakat perkotaan memiliki nilai serta norma yang berlaku untuk menjaga keseimbangan sistem masyarakat. Nilai serta norma yang ada antara masyarakat perdesaan dengan perkotaan berbeda satu sama lain. Seperti yang telah dijelaskan di atas, antara perdesaan dengan perkotaan memiliki perbedaan yang krusial pada sistem solidaritasnya.

Seiring dengan keanekaragaman budaya di desa dan kota seperti yang telah dijelaskan di atas. Masyarakat memiliki istilah tersendiri untuk individu yang memiliki predikat serta prestise tertentu dalam masyarakat. Di kota-kota besar seperti di Medan, Jakarta dan Bandung, masyarakat menyebut anak-anak yang hidup di kelas menengah atas dan tinggal dengan kekayaan yang melimpah dari orang tuanya biasa disebut sebagai "anak gedongan”. Berbeda dengan masyarakat perdesaan, khususnya masyarakat pesisir di beberapa daerah seperti di Desa Bogak, Kecamatan Tanjung Tiram, Kabupaten Batubara. Masyarakat memberikan julukan "anak itik" kepada anak-anak yang membantu nelayan.

Fenomena "anak itik" tersebut merujuk pada pekerja anak-anak. "Anak itik" biasanya membantu nelayan dalam hal membersihkan kapal dan jaring, bahkan tidak jarang “anak itik" juga ikut melaut bersama nelayan untuk mencari ikan atau hasil laut lainnya. Dengan kata lain, "anak itik" merupakan pekerja di sektor informal.

"Anak itik" di Desa Bogak merupakan bagian dari budaya yang ada di Desa Bogak. “Anak itik" juga merupakan bentuk sosialisasi pendewasaan dari masyarakat melalui ranah pekerjaan dengan harapan nantinya para pekerja anak tersebut menjadi individu yang sukses dan mandiri. Dengan kata lain, "anak itik" merupakan bagian dari kearifan lokal yang ada di Desa Bogak.

Selain itu, faktor ekonomi dari keluarga serta kebutuhan tenaga kerja dari nelayan yang ada sering kali mengakibatkan hak-hak anak tereksploitasi dikarenakan 
pekerjaan mereka. Tidak hanya dari orang yang mempekerjakan mereka saja, namun juga pihak keluarga sendiri mengabaikan hak-hak anak tersebut untuk dapat bermain dan menghabiskan waktu bersama teman-teman sebaya mereka. Hukum perlindungan hak asasi manusia khususnya anak-anak telah ditetapkan, fenomena di masyarakat baik di perkotaan maupun di desa masih banyak yang mengabaikan aturan-aturan tersebut. Lebih jauh lagi, fenomena tersebut nampaknya telah menjadi kebiasaan tersendiri di beberapa daerah. Sebagai contoh adalah masyarakat di Desa Bogak, Kabupaten Batubara. "Anak itik" merupakan manifestasi dari pekerja anak di desa pesisir tersebut.

Pekerja anak merupakan salah satu bentuk pelanggaran HAM terhadap anak. Menurut UU No. 23 tahun 2002 tentang perlindungan anak, usia yang digolongkan sebagai anak-anak adalah usia 18 tahun kebawah. Kemudian lebih lanjut dalam pasal 4 dijelaskan bahwa setiap anak berhak mendapatkan kehidupan yang layak sesuai dengan usia mereka. Kenyataan yang terjadi pada pekerja anak adalah hal yang tidak sesuai dengan undang-undang tersebut. Jika ditelaah lebih jauh lagi, "anak itik" merupakan pekerja anak yang dilarang dalam hukum positif dan tentunya melanggar undang-undang tersebut.

"Anak itik" di Desa Bogak dipekerjakan oleh toke dan nelayan untuk membantu mereka dalam berbagai jenis pekerjaan dari yang sulit hingga yang mudah seperti mengutip ikan di sampan. Terjadi perubahan konsep pada "anak itik" di Desa Bogak ketika mereka ikut melaut bersama nelayan. Ketika mereka ikut melaut maka mereka dikategorikan sebagai anak buah kapal (ABK). Maka ketika "anak itik" berada di kapal dan ikut melaut bersama nelayan, pekerjaan yang mereka lakukan tentu berbeda dari hanya sekedar membersihkan kapal di pelabuhan.

Fenomena "anak itik" yang ada di Desa Bogak merupakan bentuk nyata dari mutualisme antara eksploitasi industrial dan kearifan lokal yang ada pada masyarakat tersebut. Orang-orang yang mempekerjakan mereka tidak jarang adalah orang tua mereka sendiri yang bekerja sebagai nelayan. Adanya keinginan "anak itik" untuk membantu orang tua mengakibatkan "anak itik" ikut membantu nelayan dengan banyak mengabaikan hak-hak mereka serta memenuhi keinginan masyarakat sebagai salah satu bentuk kearifan lokal diri bagi mereka. Lebih jauh lagi, kearifan lokal tersebut bertentangan dengan hukum positif yang ada, dikarenakan hak-hak anak yang tidak dipenuhi oleh keluarga maupun masyarakat.

Hal tersebut adalah salah satu dari bentuk kekerasan simbolis yang dirasakan oleh "anak itik" di desa tersebut. Secara tidak sadar "anak itik" telah mengalami kekerasan yang tidak disadari oleh mereka dalam bentuk 
pengabaian hak-hak mereka, serta korban dari mutualisme antara eksploitasi masyarakat industri dengan kearifan lokal. Pengabaian hak-hak mereka yang tidak mereka sadari dengan jelas merupakan kekerasan simbolis yang dialami oleh pekerja anak di Desa Bogak tersebut. Penelitian ini memiliki tujuan untuk mengidentifikasi bagaimana sosialisasi yang dilakukan oleh masyarakat kepada "anak itik", serta untuk menerangkan bagaimana kekerasan simbolik yang dirasakan oleh "anak itik".

\section{METODOLOGI}

Metode penelitian yang digunakan dalam penelitian ini adalah penelitian kualitatif. Teknik pengumpulan data yang dipakai adalah dengan observasi, observasi, dokumentasi, wawancara mendalam dan penghayatan. Penelitian ini dilakukan di Desa Bogak, Kecamatan Tanjung Tiram, Kabupaten Batubara. Informan dalam penelitian ini adalah "anak itik", nelayan atau "tekong", orang tua "anak itik" dan mantan "anak itik". Hal terakhir yang dilakukan adalah interpretasi data.

Semua data yang diperoleh pada umumnya masih dalam bentuk catatan lapangan, dokumentasi resmi dalam bentuk foto, maupun dalam bentuk rekaman. Setelah data tersebut dibaca, dipelajari dan ditelaah. Maka langkah selanjutnya adalah mengadakan reduksi data dengan cara abstraksi. Abstraksi merupakan rangkuman yang terperinci dan merujuk pada inti temuan data dengan cara menelaah pernyataan-pernyataan yang diperlukan agar tetap berada pada fokus penelitian. Setelah itu data tersebut disusun dan dikategorisasikan serta diinterpretasikan secara kualitatif sesuai metode penelitian yang telah ditetapkan.

\section{HASIL}

\section{Profil "Anak Itik" Di Masyarakat Pesisir} Desa Bogak

Salah satu pekerjaan yang ada di pelabuhan dan tangkahan adalah "anak itik". Usia "anak itik" yang masih tergolong anakanak (15-18 tahun) dimaksudkan sebagai bentuk sosialisasi laut terhadap generasi berikutnya dari generasi sebelumnya. Untuk lebih memahami lebih dalam lagi mengenai profil "anak itik", berikut ini adalah penjelasannya.

Komposisi "anak itik" yang ada di pelabuhan dan tangkahan di Desa Bogak adalah anak-anak (15-18 tahun) dan remaja baik sudah menikah atau belum menikah (1825 tahun) serta dari berbagai kalangan kelas ekonomi. Dengan kriteria pekerjaan yang dianggap mudah, "anak itik" dipilih sebagai pekerjaan oleh anak-anak dan pemuda yang ada di Desa Bogak untuk membuat mereka bisa mandiri.

Pekerjaan "anak itik" hanya dikerjakan oleh laki-laki saja. Bahkan semua pekerja ("tekong", nelayan dan ABK) adalah laki-laki. Masyarakat Desa Bogak memiliki pandangan bahwa yang pelaut hanya boleh dilakukan oleh 
kaum laki-laki saja. Hal itu dikarenakan berbagai resiko yang akan dihadapi dan kemampuan laki-laki dianggap lebih tangguh dan cekatan ketika berada di laut.

Peneliti menemukan masih banyaknya anak-anak yang bekerja sebagai "anak itik" dengan berbagai alasan. Meskipun demikian, penghasilan "anak itik" yang ditentukan oleh berapa banyaknya kapal yang ditangani akan menentukan seberapa besar pendapatan yang akan diterima oleh "anak itik" tersebut dianggap dapat menghidupi keluarga, sehingga banyak juga kepala keluarga yang bekerja sebagai "anak itik".

Berdasarkan data lapangan, hampir seluruh anak-anak yang bekerja sebagai "anak itik" berhenti bersekolah (tamat SD dan belum tamat SD) pada tingkat SD (Sekolah Dasar) dan memilih untuk menjadi "anak itik" dan kemudian bercita-cita untuk menjadi "tekong" ketika mereka sudah dewasa kelak. Peneliti menemukan bahwa "anak itik" lebih menikmati dirinya bekerja menjadi "anak itik" yang dianggap sudah pasti mendapatkan uang, daripada harus bersekolah.

\section{Kondisi Sosial Ekonomi "Anak Itik" Pesisir}

Sebagaimana pekerja lainnya, "anak itik" juga termasuk buruh yang bekerja kepada nelayan atau "tekong" dan kemudian dibayar dengan uang sesuai dengan apa yang telah disepakati. Pekerjaan "anak itik" akan terus ada selama kapal-kapal dan sampan milik nelayan atau "tekong" ditambatkan. Dengan demikian, penghasilan yang didapat oleh "anak itik" akan selau ada jika "anak itik" bekerja terus-menerus tanpa kenal lelah.

Pekerjaan "anak itik" dapat dibagi menjadi 2 periode, yaitu ketika kapal ditambatkan dan ketika kapal melaut. Umumnya, "anak itik" hanya bekerja untuk satu kapal atau sampan saja, tetapi ada juga "anak itik" yang bekerja lebih dari 1 kapal atau sampan. Masing-masing periode sangat berpengaruh dengan aktivitas yang dikerjakan oleh "anak itik", dari mulai pendapatan hingga pengeluaran "anak itik" tersebut.

Pada periode dimana nelayan pergi melaut, sebagian besar "anak itik" akan beristirahat dan bermain bersama teman-teman mereka. Pemanfaatan waktu luang ini dimaksudkan untuk menghabiskan uang yang mereka dapatkan setelah mereka bekerja. Permainan yang mereka mainkan biasanya adalah permainan online yang ada di warnet (warung internet) dan playstation yang ada di Desa Bogak.

Berbeda halnya jika "anak itik" ingin ikut melaut bersama dengan $\mathrm{ABK}$ dan nelayan. "Anak itik" juga diperbolehkan ikut melaut bersama dengan nelayan dan ABK jika dalam satu kapal tersebut kekurangan ABK. Dalam satu kapal besar biasanya dibutuhkan ABK minimal 10 orang. Apabila ABK hanya ada 9 maka "anak itik" diperbolehkan ikut untuk memenuhi kapasitas kapal tersebut. Pada saat "anak itik" ikut melaut, maka 
predikatnya telah berubah menjadi ABK (Anak Buah Kapal) juga. Berbeda dengan ABK, "anak itik" akan menerima upah $2 \mathrm{x}$ lipat dati $\mathrm{ABK}$ atau 2 bagi, dikarenakan pekerjaan mereka sebagai "anak itik" dan ABK. Seperti yang diungkapkan oleh Acim Beel (64 tahun) sebagai berikut:

"Dalam 1 kapal itu ada 15 orang, "anak itik" ini bisa dibawa. Nah, kalau dia ikut, otomatis dia dapat 2 bagi. Karenakan dia tadi sudah kerja jadi "anak itik" terus ikut juga kelaut jadi ABK." (Wawancara dengan Acim Beel (64 tahun)).

Pekerjaan "anak itik" yang dikerjakan oleh anak-anak di Desa Bogak tidak ada yang melarang, selama mereka tetap berlaku jujur dan mempunyai kemampuan yang dibutuhkan oleh nelayan dan "tekong" untuk dipekerjakan. Hal tersebut juga berlaku jika mereka mempunya kemampuan untuk menjadi seorang ABK (Anak Buah Kapal).

Sebagai salah satu pekerja yang ada di pelabuhan dan tangkahan, "anak itik" sudah mengetahui kapan kapal akan melaut dan kapan kapal akan pulang atau berlabuh. Kebiasaan dan jadwal yang sudah diketahui "anak itik" tersebut mengharuskan "anak itik" untuk selalu siap sedia di pelabuhan, sehingga apabila nelayan tuan yang memekerjakan “anak itik" pulang, maka "anak itik" tersebut harus segera menanggungjawabi kapal atau sampan milik nelayan tersebut.

"Anak itik" tidak dapat menanggungjawabi kapal atau sampan milik nelayan lain dalam waktu yang bersamaan. Nelayan atau "tekong" yang memekerjakan "anak itik" sudah memberikan tanggungjawab penuh terhadap "anak itik" untuk menjaga kapal atau sampan mereka. Pekerjaan "anak itik" ketika kapal atau sampan milik nelayan berlabuh bagi masyarakat Desa Bogak adalah pekerjaan "anak itik" yang sebenarnya. Berbagai kebutuhan kapal dipenuhi oleh "anak itik". Mulai dari mengisi minyak, membeli persediaan makanan, membersihkan kapal, membeli es, memasang tenda dan hal lainnya yang diperintahkan oleh nelayan atau "tekong" kepada "anak itik".

\section{DISKUSI}

\section{"Anak Itik" Sebagai Bagian Dari}

\section{Masyarakat Pesisir}

Masyarakat adalah sebuah sistem yang memiliki berbagai unsur yang saling berhubungan satu dengan yang lainnya (Poloma, 2010). “Anak itik” juga merupakan salah satu unsur yang terdapat pada masyarakat pesisir Desa Bogak. Sebagai salah satu unsur dalam sebuah sistem, "anak itik" mempunyai pengaruh yang besar dalam masyarakat Desa Bogak.

Sosialisasi “anak itik" sudah berlangsung sejak turun temurun di masyarakat Desa Bogak. Anak-anak di Desa Bogak harus diperkenalkan dengan laut agar kebudayaan dan tradisi di masyarakat tersebut tetap terjaga dan dilestarikan. "Anak itik" yang merupakan bagian dari kearifan lokal 
masyarakat Desa Bogak dianggap penting untuk diajarkan kepada generasi penerus.

Sejak usia dini, anak-anak di Desa Bogak biasanya akan bermain di dekat sungai. Sudah menjadi pemandangan umum untuk melihat anak-anak di Desa Bogak beranang dan bermain air di sungai yang ada di Desa Bogak, lokasi tempat mereka berenang tentunya adalah lokasi yang aman untuk mereka. Disekitar mereka, biasanya ada nelayan yang sedang merajut jaring atau sekedar memperbaiki kapal atau sampannya.

Pengajaran tentang laut sudah diajarkan sejak dini oleh masyarakat Desa Bogak dengan membiarkan anak-anak mengeksplorasi alam sekitar mereka yang sebagian besar adalah perairan dan laut. Kemudian secara perlahan, bagi anak-anak yang berminat akan diajak untuk menjadi "anak itik" dan kemudian bekerja kepada nelayan atau "tekong".

Keluarga adalah kelopok terkecil dalam masyarakat. Segala bentuk kebudayaan serta adat istiadat yang ada di masyarakat, disosialisasikan secara efektif oleh keluarga. Keefektifan sosialisasi tersebut dikarenakan keluarga adalah arena pertama bagi individu untuk berinteraksi.

Masyarakat Desa Bogak sangat menghormati adat istiadat yang ada pada masyarakat mereka. Meskipun sudah banyak etnis pendatang yang ada di Desa Bogak, tetapi kearifan lokal seperti "anak itik" tetap dilestarikan oleh masyarakat. Hal tersebut dikarenakan "anak itik" merupakan media yang sangat efektif bagi anak-anak untuk dapat berkembang menjadi individu yang dewasa menurut masyarakat Desa Bogak. Berdasarkan asumsi bahwa "anak itik" adalah proses pendewasaan diri bagi anak-anak di Desa Bogak, maka masyarakat senantiasa menjaga dan mensosialisasikan "anak itik" secara turun temurun, baik dari lingkungan keluarga ataupun lingkungan di luar keluarga.

Melalui keluarga, "anak itik" di Desa Bogak disosialisasikan dan diajarkan secara turun temurun. Dalam satu keluarga nelayan di Desa Bogak, jika ayahnya seorang nelayan, maka anak laki-lakinya akan ada yang mengikuti jejak ayahnya untuk menjadi nelayan. Meskipun tidak dapat dipungkiri bahwa faktor seorang anak untuk bekerja bermacam-macam, tetapi untuk pekerjaan "anak itik" sedikit berbeda. Perbedaan tersebut dikarenakan "anak itik" adalah salah satu kebudayaan dan kearifan lokal di masyarakat pesisir Desa Bogak.

Sebagai bagian dari keluarga, seorang anak akan diperlakukan sebagaimana mestinya oleh orang tua mereka. Seorang anak akan diberikan perhatian lebih, serta ditanggungjawabi segala kebutuhannya. Hal serupa juga dialami oleh anak-anak yang bekerja sebagai “anak itik”. Kedua orang tua serta sanak keluarganya akan memberikan perhatian dan segala kebutuhannya akan 
dipenuhi. Anak-anak yang bekerja sebagai "anak itik" tidak dibedakan oleh kedua orang tua mereka dengan anak yang lainnya.

Pekerja-pekerja yang ada dalam sistem sosial masyarakat Desa Bogak memiliki peran dan fungsinya masing-masing. Hubungan antara pekerja satu dengan yang lainnya berjalan dengan baik meskipun tetap ada persaingan. Hal tersebut juga dirasakan oleh anak-anak yang bekerja sebagai "anak itik". "Anak itik" diperlakukan sebagaimana mestinya seperti pekerja lainnya.

Dalam lingkungan kerja, "anak itik" berada pada strata terendah dikarenakan pengalaman, upah yang diterima serta komposisi usianya. Oleh karena itu, tidak jarang ABK (Anak Buah Kapal) juga sering meminta tolong kepada "anak itik" untuk membeli sesuatu atau hanya sekedar orang yang diperintah (disuruh-suruh). Meskipun demikian, hal tersebut dianggap sebagai hal yang biasa bagi masyarakat Desa Bogak, khususnya anak-anak yang bekerja sebagai "anak itik".

Lingkungan kerja dapat menjadi media sosialisasi efektif kedua setelah keluarga bagi anak-anak yang bekerja sebagai "anak itik" tentang laut. Keefektifan tersebut dikarenakan anak-anak yang bekerja sebagai "anak itik" akan merasakan langsung bagaimana berhadapan dengan laut sebagai bagian dari pekerjaannya. Selain itu, berbagai pembicaraan serta pembelajaran yang diberikan oleh pekerja lain seperti nelayan, "tekong" dan ABK tidak terlepas dari bagaimana menjadi seorang pelaut yang handal.

\section{Hak dan Kewajiban "Anak Itik"}

"Anak itik" merupakan salah satu pekerjaan yang ada di Desa Bogak. Pekerjaan "anak itik" berbeda dengan pekerja pada umumnya. Perbedaan tersebut terletak pada komposisi pekerjanya yang memekerjakan anak-anak sebagai “anak itik”. Meskipun terdapat perbedaan usia yang signifikan dari sesame "anak itik", hak dan kewajiban "anak itik" tetaplah sama. Nelayan dan "tekong" tidak membeda-bedakan mana "anak itik" yang sudah berusia 18 tahun keatas atau mana “anak itik" yang berusia 18 tahun kebawah. Bagi nelayan dan "tekong" yang terpenting adalah "anak itik" haruslah bertanggungjawab terhadap pekerjaan mereka.

Pekerjaan "anak itik" bagi masyarakat Desa Bogak juga merupakan pilihan. Keputusan untuk menjadi "anak itik" sepenuhnya berada pada pekerja tersebut, baik itu anak-anak ataupun orang dewasa. Tidak ada paksaan dari siapapun bagi anak-anak atau orang dewasa untuk bekerja sebagai "anak itik". Memang tidak dapat dipungkiri bahwa sesekali nelayan atau "tekong" meminta orang untuk menjadi "anak itik", tetapi keputusan itu kembali kepada si pekerja, apakah dia menerimanya atau tidak menerimanya.

"Anak itik" sebagai pekerjaan yang banyak didominasi oleh anak-anak, tentunya memiliki perbedaan hak dan kewajiban dari 
orang-orang dewasa. Dalam berbagai peraturan baik itu perundang-undangan atau keputusan pemimpin, hak dan kewajiban anak-anak selalu dibedakan isi dan babnya usia lain. Anak-anak memiliki perbedaan dengan orang dewasa dalam berbagai hal, termasuk juga masalah HAM (hak azasi manusia).

Anak-anak adalah generasi penerus bangsa yang memiliki peran yang strategis, oleh karena itu anak-anak harus mendapatkan kesempatan yang seluas-luasnya untuk tumbuh dan berkembang secara optimal. Dalam rangka memberikan kesempatannya untuk tumbuh dan berkembang secara optimal, anak-anak harus beradaptasi sesuai dengan anak-anak seusianya agar selaras dengan proses pendewasaan dirinya. Hal tersebut tertera dalam UU No. 23 tahun 2002 pasal 11.

Sebagaimana dengan peraturan perundang-undangan No. 23 tahun 2002 pasal 11, penting bagi anak-anak untuk dapat bersosialisasi dan berteman dengan teman sebayanya. Dalam hal ini, anak-anak yang bekerja sebagai "anak itik" di Desa Bogak sangat banyak menghabiskan waktu mereka untuk bekerja di pelabuhan daripada bergaul dengan anak-anak seusianya. Antara "anak itik" yang satu dengan yang lain tidak terjalin hubungan yang intens sehingga "anak itik" hanya dihadapkan kepada pekerjaannya dan kemudian beristirahat setelah pekerjaannya selesai. Meskipun ada juga waktu dimana kapal sedang melaut, "anak itik" lebih memilih untuk bekerja kembali menjadi "anak itik" di kapal atau sampan lain agar mendapat penghasilan lebih daripada bermain dengan teman-teman sebayanya.

Pelanggaran akan hak-hak anak tidak disadari oleh mereka sama sekali. Perasaan bangga atas penghasilan yang mereka dapatkan menutupi pemenuhan akan hak yang seharusnya mereka dapatkan. Hal tersebut adalah salah satu bentuk dari kekerasan simbolik, yaitu kekerasan yang bersifat simbolik dan tidak disadari oleh korban (victim).

Kekerasan yang dimaksud adalah adanya hak-hak "anak itik" sebagai anak-anak yang tidak terpenuhi, bukan sebagai pekerja. Sebagai pekerja, “anak itik" diharuskan menerima upah dan perlakuan yang sama sebagaimana pekerja lain, yaitu keselamatan dan kenyamanan lingkungan kerja. Sebagai anak-anak, hak mereka adalah memperoleh kehidupan yang layak untuk seusianya, tetapi hal tesebut tidak didapatkan oleh anak-anak yang bekerja sebagai "anak itik".

Para "tekong" dan nelayan di Desa Bogak memekerjakan anak-anak sebagai "anak itik" tanpa memerhatikan hak mereka sebagai anak-anak sesuai dengan peraturan yang berlaku. Meskipun ada "anak itik" yang bekerja secara sukarela dan tidak ada paksaan, hal tersebut adalah bentuk turunan dari simbol yang ditanamkan oleh masyarakat Desa 
Bogak. Simbol tersebut adalah "anak itik" adalah proses pendewasaan diri bagi generasi muda.

Kekerasan simbolik yang dirasakan oleh anak-anak yang bekerja sebagai "anak itik" tidak disadari oleh mereka. Jika dilihat dari sudut pandang masyarakat beserta dengan "anak itik", pekerjaan "anak itik" adalah bagian dari kearifan lokal yang ada di Desa Bogak. Berbeda halnya jika dilihat dari kacamata hukum positif, pekerjaan "anak itik" yang memekerjakan anak-anak adalah pelanggaran HAM. Pelanggaran HAM yang terjadi tidak disadari oleh korbannya dikarenakan adanya konstruksi sosial, status, prestisa dan simbol yang menutupi kenyataan bahwa mereka sedang dieksploitasi HAM mereka disebut sebagai kekerasan simbolik.

Anak-anak yang bekerja sebagai "anak itik" juga merasakan adanya hal lain selain pelanggaran hak-hak mereka sebagai anakanak, yaitu perasaan lebih takut kepada nelayan atau "tekong daripada orang tua. Kepatuhan yang diberikan oleh pekerja terhadap orang yang mempekerjakan mereka biasanya disadari sebagai bentuk pertukaran antara jasa dan materi. Hubungan saling membutuhkan juga terbangun antara atasan (nelayan) dengan bawahan (ABK dan "anak itik").

Hubungan senior-junior antara nelayan dengan anak-anak yang bekerja sebagai "anak itik" memperkuat perasaan patuh "anak itik" kepada nelayan dan "tekong”. Adanya ikatan senior-junior tersebut memperkuat budaya patriarki yang ada pada masyarakat nelayan di Desa Bogak. Ketidakberdayaan junior untuk menentang senior menambah rasa takut serta rasa patuh "anak itik" kepada nelayan. Tentu saja, hal tersebut tidak disadari oleh anak-anak yang bekerja sebagai "anak itik" ataupun nelayan.

\section{Kekerasan Simbolik Pekerja Anak di Masyarakat Pesisir}

"Anak itik" merupakan profesi yang sudah diakui sejak generasi terdahulu di Desa Bogak. Sejalan dengan adanya laut sebagai sumber mata pencaharian bagi masyarakat di Desa Bogak, nilai dan norma yang berlaku semakin mantap tertanamkan melalui proses sosialisasi yang panjang di masyarakat. Berbagai nilai dan norma yang dianggap benar terus dijalankan dan diajarkan kembali ke generasi berikutnya.

Sedari dulu, pekerjaan "anak itik" banyak didominasi oleh anak-anak yang ada di Desa Bogak. Apa yang dirasakan oleh "anak itik" terdahulu dan dianggap benar, maka akan diterapkan kembali kepada "anak itik" yang sekarang dan begitu seterusnya. Penanaman nilai yang dilakukan melalui proses sosialisasi akan sangat tinggi kualitasnya jika sudah dilakukan dari generasi ke generasi.

Kekerasan simbolik yang dirasakan "anak itik" tidak hanya dirasakan oleh "anak itik" pada generasi sekarang ini, tetapi juga akan dirasakan oleh generasi berikutnya. Hal tersebut dikarenakan mata pencaharian 
masyarakat pesisir yang bergantung pada hasil laut, tentu saja akan banyak pekerjaan yang dibutuhkan untuk meningkatkan produktifitas dari masyarakat tersebut.

Kekerasan simbolik yang dirasakan oleh "anak itik" akan terus disosialisasikan secara turun temurun. Hal tersebut dikarenakan profesi "anak itik" dianggap sebagai media untuk pendewasaan diri bagi anak-anak di Desa Bogak dan hal tersebut sudah dianggap benar oleh masyarakat Desa Bogak. Sebagai bentuk pendewasaan diri yang ditempah melalui pekerjaan "anak itik", masyarakat mengambil contoh orang-orang sukses yang berasal dari Desa Bogak dan merupakan mantan "anak itik" di masa kecilnya.

\section{KESIMPULAN}

Masyarakat Desa Bogak adalah masyarakat pesisir yang menggantungkan hidupnya dari hasil laut. Dengan adanya infrastruktur seperti pelabuhan dan tangkahan di Desa Bogak, masyarakat memiliki banyak pilihan pekerjaan yang bisa didapatkannya untuk mencari nafkah. Pekerjaan-pekerjaan tersebut tidak lain adalah: "tekong”, nelayan, ABK (Anak Buah Kapal) dan "anak itik". Meskipun banyak pekerjaan lainnya yang ada di pelabuhan atau tangkahan (seperti: pedagang, tukang dan lain sebagainya) tetapi dalam penelitian ini, pekerjaan yang terkait langsung dengan "anak itik" adalah "tekong", nelayan dan $\mathrm{ABK}$.
"Anak itik" adalah pekerjaan yang biasa dikerjakan oleh anak-anak di Desa Bogak. Sebagaimana pekerja anak, hal tersebut adalah salah satu pelanggaran HAM menurut UU No. 23 tahun 2002 tentang perlindungan anak, dimana anak-anak seharusnya berinteraksi, berekreasi dan berkreatifitas dengan seusianya serta wajib mengenyam pendidikan dasar selama 6 tahun. Fenomena "anak itik" di Desa Bogak adalah paradox antara hukum positif dengan kearifan lokal, sehingga fenomena "anak itik" di Desa Bogak merupakan contoh kongkrit dari pertentangan antara hukum positif dengan kearifan lokal.

Menurut hukum positif yang ada, pekerja anak (termasuk "anak itik") adalah pelanggaran HAM, namun hal tersebut tidak disadari oleh "anak itik" itu sendiri. Menurut Pierre Bourdieu (dalam Jerkins, 2004), fenomena itu disebut sebagai kekerasan simbolik, yaitu kekerasan yang tidak disadari oleh individu dikarenakan berbagai simbol serta bentuk dominasi yang menutupi kekerasan tersebut. Kekerasan yang dimaksud di sini adalah ketidakterpenuhinya hak-hak "anak itik" sebagai anak-anak seperti yang tercantum dalam UU No. 23 tahun 2002 tentant perlindungan anak.

Anak-anak yang bekerja sebagai "anak itik" di Desa Bogak cenderung merasa lebih takut kepada nelayan atau "tekong" yang mempekerjakan mereka daripada kepada 
orang tua, meskipun nelayan atau "tekong" tersebut selalu bersikap baik terhadap "anak itik". Lebih jauh lagi, adanya hubungan senior junior antara nelayan dan "anak itik" menambah kokohnya ketakutan mereka terhadap nelayan atau "tekong".

Kekerasan simbolik seperti yang telah dijelaskan di atas merupakan pelanggaran HAM yang tidak disadari oleh anak-anak yang bekerja sebagai "anak itik". Meskipun demikian, eksistensi "anak itik" sudah ada sejak dahulu kala sebagaimana masyarakat pesisir sudah mencari nafkah di laut dan sudah mulai mempekerjakan anak-anak untuk membantu nelayan. Lebih lanjut lagi, "anak itik" sudah menjadi budaya yang dianggap penting bagi masyarakat Desa Bogak dan harus dilestarikan keberadaannya.

Anak-anak yang bekerja sebagai "anak itik" di Desa Bogak tidak pernah merasa mengalami adanya kekerasan dalam bentuk apapun terhadap diri mereka. Anak-anak yang bekerja sebagai "anak itik" merasa bahwa pekerjaan "anak itik" sangat membantu mereka dalam mencari jati diri dan dapat meningkatkan rasa percaya diri mereka karena sudah bisa mendapatkan uang dari hasil jerih payah mereka sendiri. Mereka merasa bahwa pelabuhan adalah rumah kedua mereka, karena di sana mereka diperlakukan secara baik oleh "tekong" dan nelayan yang mempekerjakan mereka. Begitu juga dengan ABK yang bekerja bersama mereka, "anak itik" merasa bahwa mereka semua sangat baik kepada “anak itik" yang ada di Desa Bogak.

Fenomena "anak itik" sudah ada sejak turun temurun di masyarakat pesisir Desa Bogak. "Anak itik" dianggap sebagai wadah pendewasaan diri bagi anak-anak yang ada di Desa Bogak. Nilai-nilai tentang kelautan ditanamkan kepada anak-anak melalui pekerjaan mereka sebagai “anak itik". Tidak ada paksaan bagi anak-anak untuk bekerja sebagai "anak itik". Karena pekerjaan "anak itik" tersbut dapat dikerjakan sambil bermain dan bisa dikerjakan bersama-sama dengan teman mereka untuk suatu pekerjaan tertentu.

Dengan adanya manfaat yang dirasakan oleh masyarakat Desa Bogak tersebut, "anak itik" terus disosialisasikan secara turun temurun baik di keluarga maupun di masyarakat. Anak-anak yang bekerja sebagai "anak itik" akan mendapatkan pembelajaran tentang berbagai hal (khususnya tentang laut) ketika dia bekerja.

Sosialisasi yang dilakukan oleh "tekong" dan nelayan kepada anak-anak yang bekerja sebagai "anak itik" adalah dengan memberikan pengajaran akan hal-hal baik. Hal-hal baik tersebut berupa nilai dan norma yang dianggap arif yang harus ditanamkan kedalam benak setiap individu agar menjadi pribadi yang baik serta bermanfaat bagi orang lain. 


\section{DAFTAR PUSTAKA}

Adam, Mohammad \& Fikri Hakin, (2015), Ekspor Perikanan RI Masuk Peringkat Kelima, Http://bisnis.news.viva.co.id/news/read/584824-ekspor-perikanan-ri-masukperingkat-kelima-di-dunia, diakses pada 28 Agustus 2015.

Brinkerhoff, David B, dkk, (1995), Essentials of Sociology: Third Edition, Lincoln, West Publishing Company.

Bungin, Burhan, (2007), Penelitian Kualitatif, Jakarta, Kencana.

Endrawati, Netty, (2011), Faktor Penyebab Anak Bekerja Dan Upaya Pencegahannya (Study Pada Pekerja Anak Sektor Informal Di Kota Kediri), Jurnal Ilmu Hukum Refleksi Hukum Edisi April 2011.

Ernaningsih, Wahyu, (2012), 20 Hak Anak Menurut UU No. 23 Tahun 2002 Tentang Perlindungan Anak. Jurnal Ilmiah Pusat Studi Wanita UNSRI, Vol. 3, No. 1. UNSRI.

Hannselin, James M., (2006), Sosiologi Dengan Pendekatan Membumi, Jakarta, Gelora Aksara Pertama.

Jerkins, Richard, (2005), Membaca Pikiran Pierre Bourdieu, Yogyakarta, Kreasi Wacana.

Munirob, Siti Mumun, (2011), Psikologi Keberlanjutan Sekolah Pekerja Anak Di Sektor Batik, Jurnal Penelitian Vol. 8 No. 2.

Munirob, Siti Mumun, (2013), Sekolah Ideal Pekerja Anak: Ekspektasi Dan Model Sekolah Bagi Pekerja Anak Di Pekalongan, Jurnal Penelitian Vol. 10 No.1.

Nainggolan, Lukman Hakim, (2005), Masalah Perlindungan Hukum Terhadap Anak Di Indonesia, Jurnal Equality Volume 10 No. 2.

Nasution, Arif, dkk, (2008), Metode Penelitian, Medan, FISIP USU Press.

Poloma, Margaret M, (2010), Sosiologi Kontemporer. Jakarta, Rajawali Pers.

Ritzer, George \& Barry, Smart, (2014), Handbook Teori Sosial, Jakarta, Nusa Media.

Ritzer, George \& Douglas, J. Goodman, (2010), Teori Sosiologi Modern, Jakarta, Kencana.

Robi, Rizkianto, Istiqlaliyah Muflikhati \& Neti Hermawati, (2013), Nilai Ekonomi Anak, Motivasi dan Self-Esteem Pekerja Anak. Jurnal Ilmu Keluarga dan Konsumen, Vol.6, No. 3. IPB: Bogor. 
Rochatun, Isti, dkk, (2012), Eksploitasi Anak Jalanan Sebagai Pengemis Di Kawasan Simpang Lima Semarang, Unnes Civic Education Journal 1 (1).

Sugiyono, (2008), Metode Penelitian Kuantitatif, Kualitatif dan R \& D, Bandung, Alfabeta.

Wahyuni, Lilik, (2008), Kekuasaan Simbolik Dalam Wacana Politik Di Media Cetak, Jurnal Kajian Linguistik dan Sastra Vol. 20, No. 2, Malang, PBSI-IKIP Budi Utomo.

Wirarta, Made, (2005), Metodologi Penelitian Sosial Ekonomi, Yogyakarta, Penerbit Andi.

Yin, Robert K., (2014), Studi Kasus: Desain \& Metode, Jakarta, Rajawali Pers.

\section{Sumber Internet:}

Http://www.batubarakab.go.id/, diakses pada 03 Oktober 2015.

Statistik.kkp.go.id/index.php/arsip/file/37/kpda11_ok_r06_v02.pdf， diakses pada 28 Agustus 2015.

Demartoto, Argyo, (2013), Teori Konstruksi Sosial dari Peter L. Berger dan Thomas Luckman, diakses dari http://argyo.staff.uns.ac.id/2013/04/10/teori-konstruksisosial-dari-peter-l-berger-dan-thomas-luckman/ pada 19 Oktober 2015.

\section{Sumber Lain:}

UU No. 13 Tahun 2003 Tentang Ketenagakerjaan.

UU No. 23 Tahun 2002 Tentang Perlindungan Anak.

UU No. 20 Tahun 2003 Tentang Sistem Pendidikan Nasional. 